\title{
PARTICIPATION IN ORGANIZATIONS, TECHNICAL EFFICIENCY AND TERRITORIAL DIFFERENCES: A STUDY OF SMALL WHEAT FARMERS IN CHILE
}

\author{
Mónica M. Jaime ${ }^{1 *}$, and César A. Salazar ${ }^{2}$
}

\section{ABSTRACT}

The lack of efficient individual solutions for small farmers either in the market or through the State has resulted in a search for collective spaces to strengthen their productive capacities, where participation in organizations emerges as a relevant factor to obtain higher efficiency levels. The aims of this study were to analyze the determinants of technical efficiency of wheat small farmers in Bío Bío Region (Chile) and to evaluate its relation to a variety of variables, including farmer participation in organizations, for several territories with different agro-climatic conditions. Using information from the VII Agricultural and Forestry Survey, a stochastic frontier production function was estimated. The results show that age, education, farm size, degree of specialization and dependence of activity explain individual technical efficiency levels. Participation in cooperatives and gremial associations is also related to higher technical efficiency levels, especially in territories characterized for a lower wheat productive vocation.

Key words: Technical efficiency, stochastic frontier production function, participation in organizations, social capital.

\section{INTRODUCTION}

Commercial integration provides new opportunities and challenges for producers, whose capacity to adapt to the changes in consumer preferences and to compete in international markets often determine their commercial success. In the food industry, traditional products' prices have dropped, price bands have been dismantled, and agricultural importations have increased, requiring important changes in production conditions in order to continue competing. Additionally, the volatile prices of some products and inputs have generated a new, uncertain dynamic that has principally affected small farms.

In Chile, as in many countries, small farmers have little negotiating power with respect to the food processing industry, which is the principal buyer of their products. Additionally, the farmers' limited knowledge about appropriate technology limits their opportunities to access more convenient price and distribution channels. The high

${ }^{1}$ Universidad de Concepción, Escuela de Administración y Negocios, Av. Vicente Méndez 595, Casilla 537, Chillán, Chile.

*Corresponding author (mjaime@udec.cl).

${ }^{2}$ Universidad del Bío-Bío, Facultad de Ciencias Empresariales, Av. Collao 1202, Casilla 5-C, Concepción, Chile.

Received: 25 March 2010.

Accepted: 9 November 2010. debt and low capitalization levels have made access to credit even more difficult, complicating risk management (Bravo-Ureta and Pinheiro, 1993; ProChile, 2009).

The lack of efficient individual solutions for small farmers either in the market or through the State has resulted in a search for collective spaces to strengthen their productive capacities, where participation in cooperative or gremial organizations emerges as a relevant factor to obtain higher efficiency levels, especially in territories that do not have favorable conditions for these activities.

The affiliation and participation of small farmers can be analyzed using the social capital approach, which studies the "characteristics of social organizations including interrelations, norms and trust that facilitate cooperation and coordination for mutual benefit" (Putnam, 1995). The distinct expressions of social capital emanate principally from the relations of participation and trust in social organizations, and several authors consider it to be an asset (together with human capital and physical and financial capital) that can contribute to improved levels of social and economic development (Knack and Keefer, 1997; Aker, 2007). The existence of social capital can also explain the differences observed in the different economic results between agents (Grootaert and Narayan, 2004).

According to Amtmann et al. (1998), small farmers principally produce traditional crops such as wheat, oats, 
maize, and potatoes, and do not adopt more risky yet more profitable crops due to technical and financial limitations. Since they generally do not hire salaried workers and have low levels of operational capital, they have low production levels and high production costs. Additionally, they have management problems, which directly impact on their business even when a large percentage of their production supplies national and international markets, principally through the food processing industries (Rojas, 2009). Moreover, despite their low productivity, small farm production represents $44 \%$ of annual production in Chile, ratifying their relevance (INDAP, 2009).

Since individual solutions are inefficient, many of the policies targeted to small farmers are oriented towards farmer associations. According to INDAP (2009), participation in associations should help small farmers achieve economies of scale, reduce transaction costs, provide access to technical and management services, negotiate production and input volumes that are attractive to the market, initiate post-harvest management, and develop value added products. Berdegué (2001) argues that participation in organizations could improve the performance of their members in the market. Thus, it can be seen as a resource that provides farmers with the opportunity to improve their efficiency conditions in a scenario that there is no individual solution (Habermas, 1989).

The aims of this study were to analyze the determinants of technical efficiency in small wheat farmers in the Bío Bío Region, southern Chile and determine if social capital, measured as participation in organizations, contributed to improved technical efficiency levels for a set of territories that present a certain degree of differences in their agroclimatic conditions. Using the information from the VII Agricultural and Forestry Survey (INE, 2007), a stochastic frontier production function was estimated.

\section{MATERIALS AND METHODS}

\section{Stochastic frontier production function}

The theoretical framework to calculate the technical efficiency measurements was initially proposed by Farrell (1957), who assumed the specification of an efficient production frontier defined as the maximum quantity of product that can be obtained from a set of inputs. Based on this, technical inefficiency is calculated by the difference between this theoretical maximum and the quantity that each firm really produces. Using this model, efficiency levels can be calculated as a percentage of the most efficient unit of the sample. To estimate this function, the literature proposes two alternative approaches: parametric and non-parametric. Non-parametric techniques use mathematical programming and are usually referred to as Data Envelopment Analysis (DEA), which measure inefficiency through the deviations of the observed values with the estimated frontier. These methods are less restrictive, although they cannot be used to measure random factors such as climate and natural disasters, which may influence the shape and position of the estimated frontier.

On the other hand, parametric techniques econometrically estimate the production function, allowing statistical inference on the estimated frontier. The pioneer works of Aigner et al. (1977) and Meeusen and van den Broeck (1977) are especially important because they propose a stochastic production function to differentiate between the presence of the model's measurement errors and the errors explained by inefficiencies. This differentiation requires the definition of a functional form for the production function and a distribution for the error.

Within the original proposal of the stochastic frontier approach, there is a large quantity of literature related to its development, extension, and applications. Kumbhakar et al. (1991) and Reifschneider and Stevenson (1991) propose a stochastic frontier model in which the inefficiency measures are explained in function of a vector of variables associated to the firm. Battese and Coelli (1992) generalize for the case of panel data in order to estimate technological change and inefficiency over time.

Subsequently, Battese and Coelli (1995) extend the work of Kumbhakar et al. (1991) to impose the assumption of allocative efficiency and propose a twostage model in order to simultaneously estimate each firm's production function and the determinants of its inefficiency, including transversal and panel data (for further information see Bauer, 1990, Bravo-Ureta and Pinheiro, 1993; Bravo-Ureta et al., 2007). In the first stage, the efficient production frontier is estimated as a function of control variables:

$$
\mathrm{Y}_{\mathrm{i}}=f\left(x_{\mathrm{i}} \beta\right) \exp \left(V_{\mathrm{i}}-U_{\mathrm{i}}\right)
$$

where $Y_{i}$ is the production of the $i$-th observation, $x_{i}$ is a vector of explanatory variables related to production inputs and other control variables of the $i$-th observation, $\beta$ corresponds to a vector for parameters to be estimated, is for the random variations in production due to observation and data measurement errors, uncontrollable factors etc., which are assumed iid $N\left(0, \sigma_{\mathrm{v}}^{2}\right)$. Finally, the term $U_{i}$ is a random, non-negative variable, which is associated with the measure of technical inefficiency that corresponds to the $i$-th observation.

In the second stage, a function that relates the inefficiency measurement (calculated in the first stage) with a set of explanatory variables is estimated: 


$$
U_{\mathrm{i}}=\mathrm{zi}_{\mathrm{i}} \delta+W_{\mathrm{i}}
$$

where the term $U_{i}$ can be specified from a truncatednormal distribution in zero with mean $\mu$ and constant variance $\sigma_{U}^{2}\left(U \approx \operatorname{iid} / N\left(\mu, \sigma_{U}^{2}\right)\right)$ or, with a half normal distribution $U \approx$ iid / $\left.N\left(0, \sigma_{U}^{2}\right)\right) . z_{i}$ is a vector of variables explaining the technical production inefficiency of the $i$-th observation, $\delta$ is a vector of the parameters to estimate, and $W_{i}$ refers to the error term.

The parameters of Equations [1] and [2] can be consistently estimated using the maximum likelihood method. The variance parameters of the likelihood function are estimated from the model's total variance, which is defined as $\sigma_{T}^{2}=\sigma_{V}^{2}+\sigma_{U}^{2}$. This information is used to calculate the parameter $\gamma=\frac{\sigma_{U}^{2}}{\sigma_{T}^{2}}$, which refers to the proportion of total variance that is explained by the variance of inefficiencies and whose values are between 0 and 1.

Finally, the technical production inefficiency for the $i$-th observation is defined as:

$$
T E_{\mathrm{i}}=\exp \left(-U_{\mathrm{i}}\right)=\exp \left(-\mathrm{Z}_{\mathrm{i}} \delta-W_{\mathrm{i}}\right)
$$

There is a large quantity of empirical applications that study the determinants of technical efficiency levels in agriculture. Battese and Coelli (1995), in an application in India, found that older farmers with higher education levels are more inefficient. In a similar study in India, Coelli and Battese (1996), by estimating a total value of output frontier, discovered greater efficiency levels in the case of farmers who manage larger plots, and are older and more educated. On the other hand, Amaza and Olayemi (2002) estimated stochastic production frontiers in Nigeria, finding that education, improved access to technical assistance and crop diversification increase technical efficiency levels. Demir and Mahmud (2002) proposed the estimation of a regional production added value frontier to evaluate the relation between agro-climatic and environmental conditions and technical efficiency in Turkey. Their results show that the omission of these factors substantially affect production elasticities and efficiency measurements.

In the case of rice production, Villano and Fleming (2006) find that characteristics such as age, educational level, ratio of adults to children in the home, and the amount of non-agricultural income have significant effects on technical efficiency for a sample of farmers in the Philippines. Similarly, Tian and Wan (2000) analyzed the determinants of technical efficiency associated to rice, wheat (Triticum aestivum L.) and maize (Zea mays L.) production in China, finding evidence of a positive relation between education and efficiency in the case of wheat and maize and a direct relation with farm size and the adoption of a multiple crop system in the case of rice production. More information on wheat crop efficiency can be found in Battese et al. (1993), Battese and Broca (1997), Giannakas et al. (2001) and Ahmad et al. (2002).

In the case of Chile, Moreira et al. (2006) estimated technical efficiency measurements to evaluate the impact of the implementation of a management center that provide technical assistance to small dairy farms in the Los Rios Region, finding a drop in inefficiency levels as well as evidence of technological change during the study period. Santos et al. (2006) analyze the technical efficiency of a sample of potato (Lycopersicon esculentum Mill.) farmers in the Maule Region by estimating a gross income frontier model and concluded that the following variables had a significantly direct effect on technical efficiency: the property size, the age of the head of family, the distance from the farm to the main road, and being a member of a technology transfer group. Finally, Bravo-Ureta et al. (2008), using samples of dairy farms from Chile, Argentina and Uruguay, estimated stochastic production functions to calculate measurements for economies of scale as well as rates of technological change and technical efficiency.

\section{Data and variables}

This study uses data from the VII National Agriculture and Forestry Census (INE, 2007), which is a system of continuous statistics whose objective is to have information on the state of agricultural and forestry resources in Chile.

The econometric estimates were performed on a sample of 5580 individual wheat farmers in the Bío Bío Region. Considering information restrictions and definitions of "small farmers", we selected farmers with less than 20 ha without irrigation or 15 ha with irrigation. Since information on labor and machine use is reported in general terms for each farm and not for each crop, our sample includes farms where wheat covers at least $50 \%$ of the agricultural land in order to guarantee an association between the use of these factors and wheat production. According to the Census, this Region has the second largest wheat production in Chile with $30.8 \%$ of the total farms in Chile, indicating the importance of this activity in the Region's productive development.

To estimate the stochastic production frontier, the following function was defined:

$$
\begin{gathered}
Y_{\mathrm{i}}=b_{0}+b_{1} H_{e c t_{\mathrm{i}}}+b_{2} \text { Irrig }_{\mathrm{i}}+b_{3} L a b_{\mathrm{i}}+ \\
b_{4} \text { Cap }_{\mathrm{i}}+b_{5} A l_{\mathrm{i}}+V_{\mathrm{i}}-U_{\mathrm{i}}
\end{gathered}
$$


where $Y_{\mathrm{i}}$ corresponds to the logarithm of the wheat production for farmer $i$, Hect $_{i}$ is the logarithm of the surface area (ha) planted with wheat for farmer $i$, Irrig is the logarithm of the proportion of irrigated land, $L a b_{i}$ is the logarithm of the number of permanent and temporary employee on each farm, $\mathrm{Cap}_{i}$ is the logarithm of physical capital represented by an asset index built using the Principal component analysis (PCA). Principal component analysis is a technique used to extract the linear orthogonal combinations that best explain the information from a set of variables. This index used information available with respect to ownership or use of machinery and other equipment such as a threshing machine, rakes, dusters, tractors, and number of warehouses.

To control for the factors related with territorial differences, the variable $A l_{\mathrm{j}}$, which refers to land use, was used as a proxy of the agricultural nature of territory $j$. A territory is defined as a set of counties that are organized in function of institutional, physical and economic parameters. The proxy variable is the quotient between the use of agricultural soil $\left(\mathrm{km}^{2}\right)$ and the total surface area of the territory $\left(\mathrm{km}^{2}\right)$. This variable was constructed using information from the Evaluation and Survey of Native Vegetative Resources (CONAF-CONAMA, 1997). The values $V_{i}$ correspond to measurement errors of the variables and/or errors of production frontier specification, while the term $U_{i}$ reflects the technical inefficiency of the productive process. Equation [4] was estimated for the Coob-Douglas and Translog specifications.

Subsequently, the measurements of technical inefficiency are explained by a vector of farm specific variables:

$$
\begin{gathered}
U_{\mathrm{i}}=d_{0}+d_{1} A g e_{\mathrm{i}}+d_{2} E d u c_{\mathrm{i}}+d_{3} \text { Adm }_{\mathrm{i}}+ \\
d_{4} I n t_{\mathrm{i}}+d_{5} \text { Size }_{\mathrm{i}}+d_{6} \text { Sp }_{\mathrm{i}}+d_{7} \text { Dep }_{\mathrm{i}}+d_{8} \text { Coop }_{\mathrm{i}}+ \\
d_{9} L R_{\mathrm{i}}+d_{10} \text { Irb }_{\mathrm{i}}+d_{11} \text { Grem }_{\mathrm{i}}+d_{12} \text { Other }_{\mathrm{i}}+V_{\mathrm{i}}
\end{gathered}
$$

where $U_{i}$ represents the inefficiencies estimated for farmer $i$. The variable $A g e_{i}$ refers to the farmer's age $i, E d u c_{i}$ is a categorical variable: 0 if the farmer has no formal education; 1 if $s /$ he has partially completed elementary education; 2 if $\mathrm{s} /$ he has completed elementary education; 3 if s/he has partially completed high school, 4 if s/he graduated from high school, 5 if s/he has partially completed a technical program, 6 if s/he has completed a technical program, 7 if $\mathrm{s} /$ he has partially completed her/ his university education; and 8 if $\mathrm{s} /$ he graduated from college/university.

The variable $A d m_{i}$ has a value of 1 if the farm administrator receives a salary; and 0 if not. The variable Int $_{i}$ has a value of 1 if the farmer $i$ uses Internet, and 0 if not. The $S_{i z e_{i}}$ characterizes the farm size and indicates the number of total hectares dedicated to agriculture, while the variable $S p_{i}$ is the proportion of total hectares used for wheat production.

The variable Dep $_{i}$, which indicates the degree of dependence on agricultural activity: its value is 3 if the percentage of income from agriculture received is greater than $75 \%$ of total income, 2 when the proportion is between $50 \%$ and $75 \%, 1$ if the proportion is between $25 \%$ and $50 \%$ of total income and the value is 0 if this proportion is less than $25 \%$ of total income.

Dichotomous variables that indicate if farmer $i$ participates (or not) in organizations were incorporated. The variable Coop $_{i}$ has a value of 1 if the farmer participates in a cooperative; the variable $L R_{\mathrm{i}}$ has a value of 1 if the farmer participates in companies with limited responsibility; $\operatorname{Ir} b_{i}$ has a value of 1 if the farmer participates in an irrigation board; Grem $_{i}$ has a value of 1 if the farmer participates in a gremial organization; the variable Other $_{i}$ has a value of 1 if the farmer participates in some other organization. The base situation is when the farmer does not participate in any organization. Finally, $\delta$ is the vector of estimating parameters, and $W_{i}$ refers to model errors.

The parameters of the stochastic production frontier, the inefficiency model, and variance were estimated using the maximum likelihood method using the software Frontier 4.1 (Coelli, 1996).

The technical inefficiency model is valid when the effects are stochastic, and thus it is necessary to contrast a set of hypotheses related with the specification of the production frontier and some model assumptions. First, if the effects of technical inefficiency are stochastic, i.e., $H_{0}: \gamma=0$, then it can be hypothesized that technical inefficiency effects are not present in the function production, i.e., $H_{0}: \gamma=\delta_{0}=\delta_{1}=\ldots \delta_{7}=0$. Second, to evaluate whether the specific factors of each farm have an effect on technical efficiency, the following hypothesis is suggested: $H_{0}: \delta_{l}=\ldots \delta_{7}=0$. Finally, a test of functional specification is performed to contrast Coob-Douglas specification with the Translog-type specification. These hypotheses can be evaluated using the Likelihood ratio test, which is defined as:

$$
\lambda=-2\left(\operatorname{In}\left(L\left(H_{0}\right)\right)-\operatorname{In}\left(L\left(H_{1}\right)\right)\right)
$$

where $L\left(H_{0}\right)$ and $L\left(H_{1}\right)$ show the value of the likelihood function under the null and alternative hypothesis, respectively. If the null hypothesis is not rejected, the statistical test has a $\chi^{2}$ distribution or a mixed $\chi^{2}$ distribution with degrees of freedom equal to the difference between the estimated parameters in the null and alternative hypotheses. To evaluate the absence of the effects of inefficiencies $(\gamma=0)$, it is assumed that $\lambda$ comes approximately from a mixed $\chi^{2}$ distribution. In this 
case, the critical values for the Likelihood ratio test are obtained from Kodde and Palm (1986).

\section{RESULTS AND DISCUSSION}

A summary of the descriptive statistics of the variables used to estimate the stochastic production frontier and the inefficiency model are presented in Tables 1 and 2. The statistics show an average level of production of $7.91 \mathrm{t}$ with an average surface area of $2.3 \mathrm{ha}$, which is equivalent to a yield of $3.45 \mathrm{t} \mathrm{ha}^{-1}$. Almost $26 \%$ of all the hectares are irrigated, and on average one person is hired on each farm. Most farmers did not finish elementary school and obtain $25-50 \%$ of their income from agriculture. There are some territorial differences: the Pencopolitano Territory is principally urban with limited agriculture, while the Bío Bío Centro and Laja-Diguillín territories have the greatest percentage of land used in agricultural activities. Additionally, a low use of computerized management tools was observed since less than $2 \%$ of the farmers have Internet or a salaried manager for the farm. Finally only $18 \%$ of small wheat farmers participate in some type of organization related to productive activity: $6.4 \%$ participate in the irrigation board, $4.2 \%$ form part of a cooperative, $0.8 \%$ belongs to gremial association, and only $0.3 \%$ is involved in a company of limited responsibility.

For these types of models, the existence of stochastic effects needs to be verified in the production function associated to inefficiency and whether these are influenced by specific factors of individual farmers. To statistically evaluate these restrictions and determine the adequate functional form for the production technology, the Likelihood ratio test was used and the results are presented in Table 3.
Table 2. Participation according to type of organization.

\begin{tabular}{lc}
\hline Variable & Percentage \\
\hline Cooperative (Coop) & 4.2 \\
Limited responsibility (LR) & 0.3 \\
Irrigation board (Irb) & 6.4 \\
Gremial organization (Grem) & 0.8 \\
Other organizations (Other) & 6.3 \\
\hline
\end{tabular}

Source: Author elaboration.

The results indicate that the Cobb-Douglas specification is not appropriate and rather a Translogtype specification should be used. This result is consistent with the literature (Bravo-Ureta et al., 2007). Evidence was also found indicating the presence of stochastic effects associated to technical inefficiency and these effects can be explained by a vector of farmer-associated variables, and thus it can be concluded that the estimation of a traditional production function is not an adequate representation. Table 4 presents the coefficients estimated simultaneously for the production frontier model and the inefficiency model.

For the translog model, the estimated coefficients present the expected sign and are statistically significant in the majority of the cases. These results indicate that the planted surface area, irrigation, use of hired work, the availability and use of machinery and equipment as well as the differences observed in land use have a positive and significant effect on production levels. Indeed, the possibility of controlling the factors associated to climatic, hydrographic and environmental conditions as well as the land characteristics in the different productive zones affect the position of the estimated frontier as shown by Demir and Mahmud (2002).

Table 1. Descriptive statistics of the variables in the stochastic frontier and inefficiency models.

\begin{tabular}{lcccc}
\hline Variable & Mean & $\begin{array}{c}\text { Standard } \\
\text { deviation }\end{array}$ & Minimum & Maximum \\
\hline Production (Y) & 79.1 & 367.04 & 0 & 25000 \\
Surface area, ha & 2.3 & 2.76 & 0.1 & 20 \\
Irrigation (Irrig) & 0.26 & 0.44 & 0 & 1 \\
Work (Lab) & 0.84 & 2.53 & 0 & 60 \\
Agricultural land (Al) & 0.35 & 0.12 & 0.10 & 0.71 \\
Age (Age) & 56.9 & 14.81 & 18 & 99 \\
Education (Educ) & 1.78 & 1.59 & 0 & 8 \\
Internet (Int) & 0.018 & 0.13 & 0 & 1 \\
Hired manager (Adm) & 0.020 & 0.14 & 0 & 1 \\
Size (Size) & 3.05 & 3.91 & 0.1 & 37 \\
Specialization (Sp) & 0.79 & 0.17 & 0.5 & 1 \\
Dependency (Dep) & 0.88 & 1.12 & 0 & 3
\end{tabular}

Source: Author elaboration. The variables are expressed in levels. 
Table 3. Test of the hypotheses for the parameters of the stochastic production frontier and the inefficiency model.

\begin{tabular}{lcccc}
\hline Hypothesis $\left(\boldsymbol{H}_{\boldsymbol{0}}\right)^{\mathbf{1}}$ & Log-likelihood & Statistical test $(\lambda)$ & $\begin{array}{c}\text { Critical value } \\
\left(\boldsymbol{X}_{\mathbf{0} .95}\right)\end{array}$ & Decision \\
\hline $\mathrm{H}_{0}: \mathrm{g}=0$ & -6095.859 & 933680 & 5.14 & Reject \\
$\mathrm{H}_{0}: \mathrm{g}=d_{0}=d_{1}=\ldots=d_{12}=0$ & -6151.519 & 1045000 & 23.69 & Reject \\
$\mathrm{H}_{0}: d_{1}=\ldots=d_{12}=0$ & -56667.964 & 77890 & 21.03 & Reject \\
Cobb-Douglas technology & -5811.234 & 364429 & 24.99 & Reject \\
\hline
\end{tabular}

Source: Author elaboration.

${ }^{1}$ The critical values for the first and second hypotheses that evaluate $\gamma=0$ were obtained from Kodde and Palm (1986) in Table 1 , p. 1246, with 2 and 14 degrees of freedom, respectively

A positive, significant relation was found between the farmer's age and the inefficiency levels, which suggests that younger farmers could be more open to adopting new, better practices with respect to older farmers. Opposite results were found by Coelli and Battese (1996), who argued that age could be a proxy variable for experience, and thus positively affects technical efficiency levels. Additionally, the inverse relation found between education levels and inefficiency could be because education increases the number of opportunities, improves access to information, and facilitates learning and the adoption of new processes, promoting attitudes that look for continuous improvements in productive activities. For a discussion of the effects of education on productivity measures in agriculture, see Phillips and Marble (1986) and Phillips (1994). Evidence was also found that larger sized farmers have higher efficiency levels, which could be explained by the advantages associated with large scale production in small farms (Paul et al., 2004).

Other results indicate the existence of a positive relation between technical efficiency levels and the degree of specialization in the activity (Giannakas et al., 2001). Due to the fact that wheat is a homogenous crop in terms of its attributes, the economic efficiency could be reached when economies of scale are achieved. This finding is important for Chilean agricultural sector because of the significant percentage of the producers devoted to traditional crops. Nonetheless, there is evidence that indicates that productive diversification could improve technical efficiency levels (Amaza and Olayemi, 2002).

Similarly, evidence was found that indicate a positive association between income dependence on agricultural activity and technical efficiency levels. Due to lower schooling levels and management skills, small producers must make an effort in order to maintain their levels of production and productivity occupying much more time in the planting and harvesting. As a result, the efficiency is reduced when farmers do not depend on agricultural activity. Even though this result was expected, it contrasts with the findings of Villano and Fleming (2006), who argue that non-agricultural income can be used to
Table 4. Parameters estimated for the stochastic frontier production and the inefficiency model under CoobDouglas and Translog specifications.

\begin{tabular}{|c|c|c|}
\hline \multicolumn{3}{|c|}{ Stochastic frontier } \\
\hline $\begin{array}{l}\text { Explanatory } \\
\text { variables }\end{array}$ & Coob-Douglas & Translog \\
\hline Constant & $4.3943^{* *}$ & $4.9367^{* *}$ \\
\hline Hect & $0.9872^{* *}$ & $0.7793^{* *}$ \\
\hline Irrigitation (Irrig) & $0.0753^{* *}$ & $0.3098^{*}$ \\
\hline Work (Lab) & $0.0331^{*}$ & $0.1212^{*}$ \\
\hline Cap & $0.0719^{* *}$ & $0.1409^{* *}$ \\
\hline Agricultural land (Al) & $0.2560^{* *}$ & $1.5414^{* *}$ \\
\hline$(\mathrm{Hect})^{2}$ & & $0.0654^{* *}$ \\
\hline$(\text { Irrig) })^{2}$ & & $0.0666^{*}$ \\
\hline$(\mathrm{Lab})^{2}$ & & $-0.0302^{*}$ \\
\hline$(\mathrm{Cap})^{2}$ & & $0.0489^{* *}$ \\
\hline$(\mathrm{Al})^{2}$ & & $0.5724^{* *}$ \\
\hline (Hect)(Irrig) & & -0.0006 \\
\hline$(\mathrm{Hect})(\mathrm{Lab})$ & & $-0.0228^{*}$ \\
\hline (Hect)(Cap) & & -0.0028 \\
\hline$(\mathrm{Hect})(\mathrm{Al})$ & & $-0.1027^{* *}$ \\
\hline (Irrig)(Lab) & & $0.0131^{*}$ \\
\hline (Irrig)(Cap) & & $-0.0135^{* *}$ \\
\hline$($ Irrig)(Al) & & $-0.0687^{* *}$ \\
\hline$(\mathrm{Lab})(\mathrm{Cap})$ & & -0.0014 \\
\hline$(\mathrm{Lab})(\mathrm{Al})$ & & -0.0077 \\
\hline$(\mathrm{Cap})(\mathrm{Al})$ & & -0.0115 \\
\hline \multicolumn{3}{|c|}{ Inefficiency model } \\
\hline Constant & $3.7621^{* *}$ & $-4.3076^{* *}$ \\
\hline Age & $0.0245^{* *}$ & $0.0247^{* *}$ \\
\hline Education & $-0.3880^{* *}$ & $-0.3133^{* *}$ \\
\hline Hired manager & 0.2920 & 0.1709 \\
\hline Internet & -0.0674 & 0.6374 \\
\hline Size & $-0.2025^{* *}$ & $-0.1492^{* *}$ \\
\hline Specialization & $-3.1740^{* *}$ & $-2.7554^{* *}$ \\
\hline Dependency & $-0.4467^{* *}$ & $-0.4309^{* *}$ \\
\hline Coop & $-5.8599^{* *}$ & $-6.7704^{* *}$ \\
\hline LR & $-5.1147^{*}$ & -1.6789 \\
\hline Irb & 0.0676 & -0.0876 \\
\hline Grem & $-2.4806^{* *}$ & $-2.1237^{* *}$ \\
\hline Other & $1.8256^{* *}$ & $1.6424^{* *}$ \\
\hline$\sigma_{U}^{2}$ & $5.2523^{* *}$ & $4.9309^{* *}$ \\
\hline$\gamma$ & $0.9718^{* * *}$ & $0.9704^{* *}$ \\
\hline Log-likelihood & -5.811 .2337 & -5.629 .019 \\
\hline
\end{tabular}

Source: Author elaboration. ${ }^{* *}$ Statistically significant at $99 \%$; "Statistically significant at $95 \% ;^{+}$Statistically significant at $90 \%$. 
Table 5. Descriptive statistics for technical efficiency levels and participation according to territory.

\begin{tabular}{lcccc}
\hline Territory & Mean & $\begin{array}{l}\text { Standard } \\
\text { deviation }\end{array}$ & Minimum & Maximum \\
\hline Region & 0.6101 & 0.2035 & 0.0044 & 0.9122 \\
Participate & 0.6211 & 0.2069 & 0.0050 & 0.9042 \\
Not participate & 0.6077 & 0.2028 & 0.0045 & 0.9122 \\
Laja Diguillín & 0.6700 & 0.1727 & 0.0050 & 0.8983 \\
Participate & 0.6594 & 0.1824 & 0.0050 & 0.8829 \\
Not participate & 0.6713 & 0.1715 & 0.0066 & 0.8983 \\
Punilla & 0.6339 & 0.1903 & 0.0080 & 0.9122 \\
Participate & 0.6354 & 0.1856 & 0.0290 & 0.8956 \\
Not participate & 0.6335 & 0.1917 & 0.0080 & 0.9122 \\
Valle del Itata & 0.5040 & 0.2108 & 0.0102 & 0.9041 \\
Participate & 0.5600 & 0.2380 & 0.0102 & 0.9041 \\
Not participate & 0.4848 & 0.1973 & 0.0158 & 0.8934 \\
Bío Bío Cordillera & 0.6550 & 0.2007 & 0.0045 & 0.9018 \\
Participate & 0.6551 & 0.2029 & 0.0149 & 0.8865 \\
Not participate & 0.6549 & 0.2003 & 0.0045 & 0.9018 \\
\hline
\end{tabular}

Source: Author elaboration.

Table 6. Average technical efficiency levels according to type of organization and territory.

\begin{tabular}{lccccc}
\hline Organization & Region & Laja-Diguillín & Punilla & Valle del Itata & $\begin{array}{c}\text { Bío Bío } \\
\text { Cordillera }\end{array}$ \\
\hline Cooperative & 0.7132 & 0.7248 & 0.7258 & 0.71214 & 0.8322 \\
Limited responsibility & 0.6790 & 0.7076 & - & - & 0.3453 \\
Irrigation board & 0.6228 & 0.6441 & 0.6181 & 0.6939 & 0.5920 \\
Gremial association & 0.6766 & 0.6941 & 0.6725 & 0.3727 & 0.8105 \\
Other organization & 0.5565 & 0.6339 & 0.6083 & 0.4278 & 0.6788 \\
No organization & 0.6077 & 0.6713 & 0.6335 & 0.4848 & 0.6549 \\
\hline
\end{tabular}

Source: Author elaboration.

purchase inputs and equipment for agriculture, positively contributing to improved efficiency. However, due to the lower socioeconomic conditions that characterize Chilean small farmers, they tend to look for a non-agricultural employment in order to complement agricultural income rather than obtain additional resources to be invested in the activity.

The results show, in the majority of the cases, the existence of a positive, significant relation between participation and technical efficiency levels, where the role of cooperative and gremial associations are especially important. However, participation in other organizations had a negative effect on efficiency. A possible explication of this fact is that a series of organizations that have social or representative objectives rather than economic objectives are included within this category. Additionally, participation is more important in those territories with dispersed and low efficiency levels. Summaries of the descriptive statistics for the estimated technical efficiency levels and participation in the most important territories in terms of wheat production are presented in Tables 5 and 6 .

The average technical efficiency for small wheat farmers in the Bío Bío Region is 61.01\%; however, efficiency levels exhibit differentiated effects according to territorial characteristics and participation in organizations. At territorial level, Laja-Diguillín presents the highest efficiency, reaching values near $67 \%$, which are higher than the regional average. This territory is followed by Bío Bío Cordillera and Punilla with values around $65 \%$ and $63 \%$, respectively. Finally, Valle del Itata exhibited the lowest technical efficiency level at only $50.4 \%$.

According to the Bío Bío Regional Government (GORE, 2000), the main activities of the Punilla territory are agriculture and rural tourism, while the activities of Laja-Diguillín are agricultural industry, tourism and forestry. Both territories present convergences and productive particularities with some physical, spatial, 
climatic and land use homogeneity, which produce common potentials and opportunities for the development of horticulture and traditional crops, where cereals are important.

In the Bío Bío Cordillera territory, the main activities are forestry and agricultural activities including cattleraising and dairy, fruit orchards, apiculture, and special interest tourism. In contrast, Valle del Itata territory has limited irrigation and nutrient poor soils (granite, clay) with little filtration capacity and a high degree of erosion. Its principal productive activity is vineyards. The differentiated effects found for the estimated efficiency levels are based in these territorial differences.

With respect to the type of organization, the results show that participation in cooperatives improves efficiency in each territory, and thus this type of participation could contribute to reducing the differences observed based in territorial differences. These efficiency gains are observed to be greater in those territories where agriculture is not the principal activity (Valle del Itata and Bío Bío Cordillera, which produce only $26 \%$ of the Region's wheat production). Finally, even though participation in irrigation boards was not statistically significant, it is important in territories where water is a limited resource, such as Valle del Itata.

\section{CONCLUSIONS}

Participation in organizations is especially relevant for the least powerful social groups and an important factor in rural community development for those farmers who have limited access to resources, equipment and training as well as limited negotiation capacity, key aspects in reaching competitive and performance standards.

This study proposes a stochastic frontier model to measure the effect of participation in organizations and other variables on technical efficiency levels for a sample of farmers in different territories in the Bío Bío Region, Chile. A production frontier was estimated using productive factors such as farm size, irrigation, work, capital and territory's productive vocation. The principal components analysis was used to measure the capital factor. Additionally, specific farmer factors are evaluated to explain technical efficiency levels.

The results found that the average technical efficiency levels were around $60 \%$, which varied within the range of $0.44-91 \%$. These results indicate that there are still spaces to improve the sector's efficiency, which motivates to study the factors that determine that variability. Factors such age, educational level, farm size, degree of specialization and importance of agriculture in income significantly explain technical efficiency levels in wheat producers.
The importance of social capital, measured as the participation in organizations, emerges as an alternative to reach higher technical efficiency levels. Despite the fact that only $18 \%$ of the producers are members of organizations, efficiency is improved when individuals participate in these organizations. Thus, the strengthening of social capital in rural communities and the promotion of spaces of interaction among producers, heads of organizations and technical assistance professionals should improve technical efficiency levels. Moreover, we found that participation is more relevant in those territories where the principal productive activity is not agriculture. Social capital helps improve economic conditions of individuals who live in less productive zones. Evidence shows that producers who participate in organizations have reached, on average, higher efficiency levels when compared to individuals who carry out their productive activities by themselves. In this context, governments should reinforce efforts to improve existing space of participation and provide both monitoring and support to the existing productive organizations.

Finally, we found that cooperatives and gremial associations make the greatest contribution to improved economic results. Characteristics related with the functioning and objectives of this type of organizations could explain the achieved results. Cooperatives operate like a company with a business plan where entrepreneurial capacity is fundamental, demonstrating the importance of improved management skills for both the directors and members of the organizations as a policy target. The objectives of cooperatives to improve performance contrast with other organizations that principally look to defend its members' interests in the formulation of public policy in the sector.

\section{ACKNOWLEDGEMENTS}

This study was funded by Dirección de Investigación, Universidad de Concepción (DIUC), Grant 208.042.016.1.0

\section{RESUMEN}

Participación en organizaciones, eficiencia técnica y diferencias territoriales: El caso de la pequeña agricultura de trigo en Chile. La incapacidad del mercado y del Estado para generar soluciones eficientes desde una perspectiva individual, ha llevado a la búsqueda de espacios colectivos que conduzcan a un fortalecimiento de las capacidades productivas, en donde la asociatividad aparece como un factor relevante en la consecución de mayores niveles de eficiencia. El propósito de este estudio fue analizar los determinantes 
de la eficiencia técnica de los pequeños agricultores de trigo de la Región del Bío Bío (Chile), e indagar si existe una relación entre participación en organizaciones y eficiencia técnica para un conjunto de territorios que presentan diferencias en sus condiciones agro-climáticas. Utilizando información del VII Censo Agropecuario y Forestal, se estimó un modelo de fronteras estocásticas que incorpora factores específicos para cada productor. Los resultados sugieren que la edad, nivel de educación, tamaño del productor, grado de especialización, y dependencia de la actividad explican significativamente los niveles de eficiencia técnica. Asimismo, se evidencia la importancia de la participación en el mejoramiento de los niveles de eficiencia técnica, especialmente en el caso de las cooperativas y asociaciones gremiales, las cuales producen un mayor efecto en aquellos territorios con menor vocación para el desarrollo del trigo.

Palabras clave: Eficiencia técnica, fronteras de producción estocásticas, participación en organizaciones, capital social.

\section{LITERATURE CITED}

Ahmad, M., G. Chaudry, and I. Mohammad. 2002. Wheat productivity, efficiency, and sustainability: A stochastic production function analysis. The Pakistan Development Review 41:643-663.

Aigner, D., C. Lovell, and P. Schmidt. 1977. Formulation and estimation of stochastic frontier production models. Journal of Econometrics 6:21-37.

Aker, J. 2007. Social networks and household welfare in Tanzania: Working together to get out of poverty. Social Science Research Network (SSRN). Available at http://ssrn.com/abstract=995941 (accessed 23 June 2009).

Amaza, P., and J. Olayemi. 2002. Analysis of technical inefficiency in food crop production in Gombe State, Nigeria. Applied Economics Letters 9:51-54.

Amtmann, C., F. Mujica, and B. Vera. 1998. Pequeña agricultura en la Región de Los Lagos, Chile. Ediciones Universidad Austral de Chile, Valdivia, Chile.

Battese, G., and T. Coelli. 1992. Frontier production functions, technical efficiency and panel data: With application to paddy farmers in India. Journal of Productivity Analysis 3:153-169.

Battese, G., and S. Broca. 1997. Functional forms of stochastic frontier production functions and models for technical inefficiency effects: A comparative study for wheat farmers in Pakistan. Journal of Productivity Analysis 8:395-414.
Battese, G., and T. Coelli. 1995. A model for technical inefficiency effects in a stochastic frontier production function for panel data. Empirical Economics 20:325332.

Battese, G., S. Malik, and S. Broca. 1993. Production functions for wheat farmers in selected districts of Pakistan: An application of a stochastic frontier production function with time-varying inefficiency effects. The Pakistan Development Review 32:233268.

Bauer, P. 1990. Recent developments in the econometric estimation of frontiers. Journal of Econometrics 46:39-56.

Berdegué, J. 2001. Cooperating to compete. Peasant associative business firms in Chile. Doctoral research. Department of Agricultural Economics, Michigan State University, Michigan, USA.

Bravo-Ureta, B., V. Moreira, A. Arzubi, E. Schilder, J. Álvarez, and C. Molina. 2008. Cambio tecnológico y eficiencia técnica en predios lecheros de tres países del Cono Sur. Chilean Journal of Agricultural Research 68:360-367.

Bravo-Ureta, B., and A. Pinheiro. 1993. Efficiency analysis of developing country agriculture: A review of the frontier function literature. Agricultural and Resources Economics Review 22:88-101.

Bravo-Ureta, B., D. Solís, V. Moreira, J. Maripani, A. Thiam, and T. Rivas. 2007. Technical efficiency in farming: a metta-regression analysis. Journal of Productivity Analysis 27:57-72.

CONAF-CONAMA. 1997. Catastro y evaluación de los recursos vegetacionales nativos de Chile. Corporación Nacional Forestal (CONAF), Corporación Nacional del Medio Ambiente (CONAMA), Universidad Austral de Chile, Pontificia Universidad Católica de Chile, Universidad Católica de Temuco, Santiago, Chile.

Coelli, T. 1996. A guide to FRONTIER version 4.1: A computer program for stochastic frontier production and cost function estimation. Centre for Efficiency and Productivity Analysis. Working Paper 7/96. Department of Econometrics, University of New England, Armidale, New South Wales, Australia.

Coelli, T., and G. Battese. 1996. Identification of factor which influence the technical inefficiency of Indian farmers. Australian Journal of Agricultural Economics 40:103-128.

Demir, N., and S. Mahmud. 2002. Agro-climatic conditions and regional technical inefficiencies in agriculture. Canadian Journal of Agricultural Economics 50:269-280.

Farrel, M. 1957. A measurement of productive efficiency. Journal of the Royal Statistics Society Series A 120(3):253-290. 
Giannakas, K., R. Schoney, and V. Tzouvelekas. 2001. Technical efficiency, technological change and output growth of wheat farms in Saskatchewan. Canadian Journal of Agricultural Economics 49:135-152.

GORE. 2000. Estrategia regional de desarrollo de la Región del Bío Bío. Período 2000-2006. Gobierno Regional de la Región del Bío Bío (GORE), Concepción, Chile.

Grootaert, C., and D. Narayan. 2004. Local institutions, poverty and household welfare in Bolivia. World Development 32:1179-1198.

Habermas, J. 1989. Teoría de la acción comunicativa. Editorial Taurus, Madrid, España.

INDAP. 2009. Cifras estadísticas. Instituto de Desarrollo Agropecuario, Santiago, Chile. Available at http:// www.indap.gob.cl/index.php?option=com_content $\&$ task=view\&id=1577\&Itemid=1 (accessed 2 June 2009).

INE. 2007. VII Censo Nacional Agropecuario y Forestal. Instituto Nacional de Estadística (INE), Santiago, Chile.

Knack, S., and P. Keefer. 1997. Does social capital have an economic pay-off? A cross-country investigation. Quarterly Journal of Economics 112:1251-1288.

Kodde, D., and F. Palm. 1986. Wald criteria for jointly testing equality and inequality restrictions. Econometrica 54:1243-1246.

Kumbhakar, S., S. Ghosh, and J. McGuckin. 1991. A generalized production frontier approach for estimating determinants of inefficiency in U.S. dairy farms. Journal of Business and Economic Statistics 9:279-286.

Meeusen, W., and J. van den Broeck. 1977. Efficiency estimation from Cobb-Douglas production functions with composed error. International Economic Review 18:435-444

Moreira, V., B. Bravo-Ureta, B. Carrillo, and J. Vásquez. 2006. Technical efficiency measures for small dairy farms in southern Chile: A stochastic frontier analysis with unbalanced panel data. Archivos de Medicina Veterinaria 38:25-32.
Paul, C., R. Nehring, D. Banker, and A. Somwaru. 2004. Scale economies and efficiency in US agriculture: Are traditional farms history? Journal of Productivity Analysis 22:185-205.

Phillips, J. 1994. Farmer education and farmer efficiency: A meta-analysis. Economic Development and Cultural Change 43:149-165.

Phillips, J., and R. Marble. 1986. Farmer education and efficiency: a frontier production function approach. Economics of Education Review 5:257-264.

ProChile. 2009. Programa de la Internacionalización de la Agricultura Campesina. Pro-Chile, Santiago, Chile. Available at http://www.prochile.cl/agricultura campesina/que_es.php (accessed 2 June 2009).

Putnam, R. 1995. Bowling alone: American's declining social capital. Journal of Democracy 6:65-78.

Reifschneider, D., and R. Stevenson. 1991. Systematic departures from the frontier: a framework for the analysis of firm inefficiency. International Economic Review 32:715-723.

Rojas, H. 2009. Encadenamiento productivo de la agricultura familiar campesina. Documento de trabajo, Instituto de Desarrollo Agropecuario (INDAP). Available at http://www.indap.gob.cl/index2. php?option=com_content $\&$ do_pdf $=1 \& \mathrm{id}=1291$ (accessed 3 June 2009).

Santos, J., W. Foster, and E. Ramírez. 2006. Estudio de la eficiencia técnica de productores de papa en Chile: El rol del programa de transferencia técnica de INDAP. Economía Agraria 10:119-132.

Tian, W., and G. Wan. 2000. Technical efficiency and its determinants in China's grain production. Journal of Productivity Analysis 13:159-174.

Villano, R., and E. Fleming. 2006. Technical inefficiency and production risk in rice farming: evidence from Central Luzon Philippines. Asian Economic Journal 20:29-46. 